\title{
PENGARUH PEMBIAYAAN MUDHARABAH DAN MUSYARAKAH \\ TERHADAP RETURN ON EQUITY PADA PT. BANK PEMBIAYAAN \\ RAKYAT SYARIAH DI INDONESIA
}

\author{
Silvia Nalta, Ismed Wijaya, Haris Al Amin \\ silvianalta96@gmail.com \\ ismed.did@gmail.com \\ haris@pnl.ac.id
}

\begin{abstract}
Abstrak
Bagi hasil merupakan salah satu keunggulan dari perbankan syariah dibandingkan dengan bank konvensional karena prinsip musyarakah dan mudharabah memberikan manfaat lebih kepada sektor riil. Pendapatan dari pembiayaan investasi dan modal kerja ini akan digunakan untuk pengembalian modal bank. Penelitian ini bertujuan untuk mengetahui pengaruh pembiayaan mudharabah dan musyarakah terhadap Return On Equity (ROE) Bank Pembiayaan Rakyat Syariah. Jenis penelitian ini adalah penelitian deskriptif dengan pendekatan kuantitatif. Metode pengumpulan data menggunakan teknik dokumentasi. Analisis yang digunakan adalah analisis regresi linier berganda. Hasil penelitian secara parsial menunjukkan bahwa pembiayaan mudharabah memberikan pengaruh yang negatif dan signifikan terhadap ROE, sedangkan pembiayaan musyarakah memberikan pengaruh yang positif dan signifikan terhadap tingkat ROE. Secara simultan pembiayaan mudharabah dan musyarakah memberikan pengaruh yang signifikan terhadap tingkat ROE.
\end{abstract}

Kata kunci:pembiayaan mudharabah, pembiayaan musyarakah, ROE

\begin{abstract}
Profit loss sharing is one of excellence of islamic banking and its icon compared to the conventional banks because of the principle of partnership and justice provided more benefits to the real sector. Income from investments and working capital financing will be used to pay back the bank. The purpose of this research is to known the influence of mudharabah and musyarakah financing toward Return On Equity (ROE) Syariah Public Financing Bank. The study used descriptive research with quantitative approach. Method of data collection by documentation. The data analysis was used by multiple linear regression analysis. The result of this research by parsial showing that mudharabah financing give negative and significant influence on the level of ROE, and on musyarakah financing give positive and significant influence on the level of ROE. By simultaneous, mudharabah and musyarakah financing give significant influence on the level of $R O E$
\end{abstract}


Keywords:mudharabah financing, musyarakah financing, $R O E$

\section{PENDAHULUAN}

Salah satu faktor penting dalam pembangunan suatu negara adalah adanya dukungan dari sistem keuangan yang sehat dan stabil, demikian pula dengan negara indonesia. Sistem keuangan negara indonesia sendiri terdiri dari tiga unsur, yakni sistem moneter, sistem perbankan dan sistem lembaga keuangan non bank. Perkembangan perekonomian yang semakin komplek tentunya membutuhkan ketersediaan dan peran serta lembaga keuangan.

Perbankan di Indonesia mengalami perkembangan dengan seiring berkembangnya pemikiran masyarakat tentang system syariah yang tanpa menggunakan bunga (riba). Bank terbagi dua, yaitu bank syariah dan bank konvensional. Kedua jenis bank ini memiliki produk bank yang hampir sama, hanya berbeda pada sistem operasinya. Bank konvensional menggunakan sistem bunga, sedangkan bank syariah menerapkan sistem bagi hasil. Produk bank syariah yang menerapkan sistem bagi hasil adalah pada pembiayaan modal kerja dan investasi dalam bentuk pembiayaan mudharabah dan musyarakah.

Pembiayaan merupakan penyediaan uang atau tagihan berdasarkan persetujuan antara bank dan pihak lain yang wajib untuk mengembalikan uang atau tagihan setelah jangka waktu tertentu dengan imbalan atau bagi hasil. (Rivai, 2011:15) Pembiayaan mudharabah dan musyarakah ini memiliki perbedaan pada pembagian modal dan pengelolaan usaha, serta pembagian keuntungan. Jika pembiayaan mudharabah, pihak bank $100 \%$ menyumbangkan modal, sedangkan pihak nasabah hanya mengelola usaha saja. Pembagian keuntungan berdasarkan besar modal yang disumbangkan. Jika pembiayaan musyarakah, pihak bank dan nasabah sama-sama menyumbangkan modal dan mengelola usaha, biasanya $60 \%$ : $40 \%$. Pembagian keuntungan juga berdasarkan modal yang disertakan dalam usaha tersebut.

Tiap produk bank memberikan keuntungan bagi pihak bank, sama halnya dengan kedua pembiayaan investasi tersebut. Keuntungan itu dapat diukur dengan menggunakan rasio keuangan. Rasio keuangan yang digunakan adalah rasio Return On Equity (ROE). Alasan menggunakan rasio ini dikarenakan untuk mengetahui kemampuan bank dalam mengelola modal yang dimilikinya untuk pembiayaan mudharabah dan musyarakah.

Berdasarkan masalah yang telah dikemukakan, penulis merasa tertarik untuk mengambil tema pembiayaan bagi hasil (musyarakah dan mudharabah) dikaitkan dengan profitabilitas khususnya Return On Equity (ROE), dan penulis menuangkan permasalahan ini dengan judul "Pengaruh Pembiayaan Mudharabah dan Musyarakah Terhadap ROE Pada PT. Bank Pembiayaan Rakyat Syariah Indonesia". 
Tujuan penelitian ini adalah untuk mengetahui pengaruh pembiayaan mudharabah dan musyarakah terhadap ROE pada Bank Pembiayaan Rakyat Syariah secara parsial dan simultan.

\section{STUDI PUSTAKA}

\section{Bank Pembiayaan Rakyat Syariah}

Bank Pembiayaan Rakyat Syariah (BPRS) adalah bank yang melaksanakan kegiatan usaha berdasarkan prinsip syariah yang dalam kegiatannya tidak memberikan jasa dalam lalu lintas pembayaran.

Tujuan dan Peran Bank Pembiayaan Rakyat Syariah yaitu: (1) meningkatkan kesejahteraan ekonomi umat Islam, terutama masyarakat golongan ekonomi lemah yang pada umumnya berada di daerah pendesaan. (2) menambah lapangan pekerjaan, terutama ditingkat kecamatan sehingga dapat mengurangi arus urbanisasi. (3) membina semangat ukhuwah islamiyah melalui kegiatan ekonomi dalam rangka meningkatkan pendapatan perkapita menuju kualitas hidup yang memadai.

Produk BPRS terdiri dari: (1) Penghimpun dana yang meliputi simpanan amanah, tabungan wadiah, dan deposito mudharabah. (2) Penyaluran dana yang meliputi pembiayaan mudharabah, musyarakah bai' bitsaman 'ajil, murabahah, qardhul hasan, dan istishna'.

\section{Pembiayaan Mudharabah}

Pembiayaan mudharabah adalah kerjasama antara seorang partner yang memberikan uang kepada partner lainnya untuk di investasikan ke perusahaan komersial. Pihak bank (shahibul maal) berkewajiban memberikan dana $100 \%$ kepada nasabah (mudharib) dan nasabah hanya mengelola usaha yang sudah ditentukan oleh pihak bank. Pembagian keuntungan akan dibagi berdasarkan kesepakatan pada awal kontrak, sedangkan jika terjadi kerugian akan ditanggung oleh pemilik modal. Pengelola juga bertanggung jawab apabila kerugian itu disebabkan oleh kelalaian pengelola. (Rivai, 2012:299) Jenis pembiayaan mudharabah adalah (1) mudharabah mutlaqah, jenis usaha boleh ditentukan oleh pihak nasabah (mudharib), meskipun modal tetap ditanggung oleh pihak bank. (2) mudharabah muqayyadah, jenis usaha akan ditentukan oleh pihak bank (shahibul maal) dan nasabah hanya mengelolanya. (Antonio, 2011:97).

Ketentuan umum mudharabah yaitu, (1) jumlah modal yang diserahkan kepada nasabah sebagai pengelola modal harus di serahkan secara tunai, dapat berupa barang atau uang yang dinyatakan nilainya dalam satuan uang. (2) hasil pengelolaan modal pembiayaan mudharabah dapat diperhitungkan dengan cara revenue sharing atau profit sharing. (3) hasil dibagi sesuai persetujuan di dalam akad, pada setiap bulan atau waktu yang disepakati. (4) bank berhak melakukan pengawasan terhadap pekerjaan namun tidak berhak mencampuri urusan pekerjaan/ usaha nasabah. 


\section{Pembiayaan Musyarakah}

Musyarakah adalah akad kerjasama antara dua pihak atau lebih untuk memberikan suatu usaha tertentu dimana masing-masing pihak memberikan kontribusi dana dengan kesepakatan bahwa keuntungan dan risiko akan ditanggung bersama sesuai kesepakatan. (Naf'an, 2014 :95)

\section{Jenis}

musyarakah pembiayaan Milk), yaitu Musyarakah pemilikan tercipta karena warisan, wasiat, atau kondisi lain yang mengakibatkan pemilikan satu aset oleh dua orang atau lebih. Musyarakah kepemilikan sering juga disebut kepemilikan bersama (co-ownership) apabila dua orang atau lebih memperoleh kepemilikan bersama (joint ownership) atau kekayaan aset.(2) MusyarakahAkad (Syirkah Al-Uqud), yaitu kemitraan yang tercipta dengan kesepakatan dua orang atau lebih untuk bekerja sama dalam mencapai tujuan tertentu, Musyarkah Akad tercipta dengan cara kesepakatan dimana dua orang atau lebih setuju bahwa tiap orang dari mereka memberikan modal musyarakah. Mereka pun sepakat berbagi keuntungan bahkan kerugian. Mitra berkontribusi dana kerja serta berbagai keuntungan dan kerugian terbagi atas: Syirkah Abdan, Syirkah Wujuh, Syirkah Mufawadah.

Ketentuan umum musyarakah yaitu, (1) Semua modal disatukan untuk dijadikan modal proyek musyarakah dan dikelola bersamasama. (2) Biaya yang timbul dalam pelaksanaan proyek dan jangka waktu proyek harus diketahui bersama. (3) Proyek yang akan dijalankan harus disebutkan dalam akad.

\section{Return On Equity (ROE)}

Returnon equity (ROE)

adalah rasio yang digunakan untuk mengkaji sejauh mana suatu perusahaan mempergunakan sumber daya yang dimiliki untuk mampu memberikan laba atau ekuitas.(Irham

2012:98)Rasioinidiperolehdengancar amembagilabasetelahpajakpadatahun berjalandengan rata-rata modal disetor(equity). Semakintinggi ROE makasemakintinggi pula laba yang diperolehperusahaansehinggaprofitab ilitas bank semakinbaik. Sesuaidengansuratketetapan Bank Indonesia no 23/67/KEP/DIR, nilaibatas minimal ROE yang baikadalah $10 \%$.

Hasil Rasio ini dijadikan gambaran besarnya kembalian atas modal yang ditanamkan atau kemampuan dari modal sendiri untuk menghasilkan keuntungan bagi pemegang saham preferen dan saham biasa, selain itu juga bisa dijadikan dasar bagi kreditur dalam memberikan pinjaman terhadap perusahaan dan sebagai bahan pertimbangan bagi pihak investor dalam menanamkan modalnya.

\section{Hubungan Pembiayaan Mudharabah dan Musyarakah Terhadap Return on equity (ROE) BPRS}

Setiap bank pasti menghimpun dana dan mengalokasikan dananya untuk kegiatan lain yang menghasilkan keuntungan. Salah satu pengalokasian dana tersebut adalah pembiayaan mudharabah dan musyarakah. Kedua pembiayaan 
tersebut akan menghasilkan laba dari perhitungan bagi hasilnya. Keuntungan tersebut akan dibagi antara bank dan nasabah pengelolanya. Keuntungan tersebut akan digunakan untuk mengembalikan modal yang dialokasikan untuk pembiayaan. Tingkat pengembalian modal tersebut dapat mengukur tingkat ROE suatu bank dengan cara membandingkan keuntungan/laba dengan modal yang dimilikinya.

\section{Perumusan Hipotesis}

$\mathrm{Ha}_{1}$ : Diduga pembiayaan Mudharabah dan Musyarakah secara parsial berpengaruh positif dan signifikan terhadap ROE Pada PT. Bank Pembiayaan Rakyat Syariah di Indonesia.

$\mathrm{Ha}_{2}$ : Diduga pembiayaan Mudharabah dan Musyarakah secara simultan berpengaruh positif dan signifikan terhadap ROE Pada PT. Bank Pembiayaan Rakyat Syariah di Indonesia.

Gambar 1.1

Skema Kerangka Konseptual

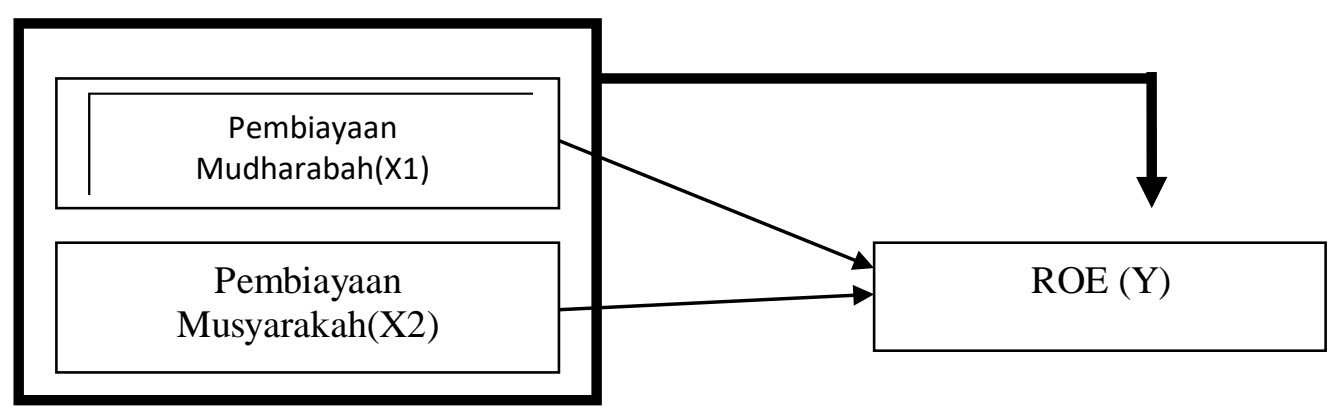

Keterangan:

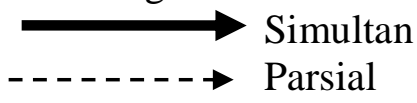

\section{METODE PENELITIAN}

Jenispenelitian

yang

digunakanadalahpenelitiandeskriptifd enganpendekatankuantitatif.Dalam penelitian ini yang menjadi variabel bebas adalah pembiayaan mudharabah dan pembiayaan musyarakah, sedangkan yang menjadi variabel terikat adalah Return On Equity.Penelitianinidilakukanpada Bank Pembiayaan RakyatSyariah (BPRS), berdasarkan data yang didapatmelalui Otoritas Jasa Keuangan.Teknikpengumpulan data 
menggunakanteknikdokumentasi,

data yang

digunakandalampenelitianiniadalah datasekunder yang menggunakanlaporankeuanganBPRS yang dipublikasikantahun 2014 2017.Teknik analisis data yang digunakan adalah analisis regresi linier berganda dan uji asumsi klasik (uji normalitas, uji multikoliniearitas, uji heterokedastisitas, dan uji autokorelasi), uji signifikansi (uji t dan uji f), serta koefisien determinasi.

\section{HASIL DAN PEMBAHASAN}

\section{Analisis dan Interprestasi Data}

Penelitian dilakukan pada Bank Pembiayaan Rakyat Syariah di Indonesia yang mempublikasikan laporan keuangan tahunan periode 2014-2017. Data yang dibutuhkan dalam penelitian ini adalah data keuangan yaitu pembiayaan mudharabah, pembiayaan musyarakah, dan Return On Equity (ROE) yang didapat melalui website Otoritas Jasa Keuangan. Di dalam laporan keuangan tahunan BPRS, pembiayaan mudharabah dan musyarakah berada pada komposisi pembiayaan yang ada di BPRS. Pada komposisi pembiayaan terdapat nominal yang menampilkan tentang pembiayaan mudharabah dan musyarakah. Sedangkan ROE dapat dilihat pada rasio keuangan BPRS di dalam laporan keuangan BPRS. Selanjutnya setelah data terkumpul, maka dilakukan pengujian dengan menggunakan SPSS.

\section{Statistik Deskriptif}

Statistik deskriptif bertujuan untuk melihat karakteristik dari masing-masing variabel yang digunakan dalam penelitian baik variabel dependen maupun variabel independen. Pada penelitian ini pembiayaan mudharabah dan musyarakah menjadi variabel independen. Sedangkan ROE menjadi variabel dependen. Hasil statistik deskriptif dari data yang digunakan dalam penelitian ini dapat dilihat dalam tabel 1.1 sebagai berikut :

Tabel 1.1

Statistik Deskriptif

Descriptive Statistics

\begin{tabular}{|l|r|r|r|r|r|}
\hline & N & $\begin{array}{c}\text { Minimu } \\
\mathrm{m}\end{array}$ & $\begin{array}{c}\text { Maximu } \\
\mathrm{m}\end{array}$ & Mean & $\begin{array}{c}\text { Std. } \\
\text { Deviation }\end{array}$ \\
\hline ROE & 48 & 13,83 & 21,61 & 16,7875 & 2,03512 \\
Ln_X1 & 48 & 11,52 & 12,15 & 11,8757 &, 16540 \\
Ln_X2 & 48 & 12,89 & 13,63 & 13,3818 &, 20027 \\
Valid N & 48 & & & & \\
(listwise) & & & & & \\
\hline
\end{tabular}

Sumber: Hasil Output SPSS Versi 20 (data diolah), 2018 
Berdasarkan hasil statistik deskriptif, jumlah data $(\mathrm{N})$ sebanyak 48 dari laporan keuangan tahunan Bank Pembiayaan Rakyat Syariah yang terdiri dari pembiayaan mudharabah, pembiayaan musyarakah, dan ROE sejak tahun 2014-2017. Variabel dependen ROE memiliki nilai minimum sebesar 13,83 dan maksimum sebesar 21,61 dimana ROE tertinggi terjadi pada bulan Februari 2014, sedangkan ROE terendah terjadi pada bulan Mei 2016. Nilai rata-rata ROE sebesar 16,7875 dengan standar deviasi sebesar 2,03512. Nilai standar deviasi yang lebih kecil dari nilai rata-rata menunjukkan bahwa simpangan data ROE baik. Pada

pembiayaan mudharabah, nilai minimum sebesar 11,52 dan maksimum sebesar 12,15 dimana pembiayaan mudharabah tertinggi terjadi pada bulan Mei 2016, sedangkan pembiayaan mudharabah terendah terjadi pada bulan Januari 2014. Nilai rata-rata pembiayaan mudharabah sebesar 11,8757 dengan standar deviasi sebesar 0,16540. Nilai standar deviasi yang lebih kecil dari nilai rata-rata menunjukkan bahwa simpangan data pembiayaan mudharabah baik.

$$
\text { Pada pembiayaan }
$$

musyarakah, nilai minimum sebesar
12,89 dan maksimum sebesar 13,63 dimana pembiayaan musyarakah tertinggi terjadi pada bulan Juni 2017, sedangkan pembiayaan musyarakah terendah terjadi pada bulan Januari 2014. Nilai rata-rata pembiayaan musyarakah sebesar 13,3818 dengan standar deviasi sebesar 0,20027. Nilai standar deviasi yang lebih kecil dari nilai rata-rata menunjukkan bahwa simpangan data pembiayaan musyarakah baik.

\section{Uji Asumsi Klasik}

Uji asumsi klasik ini digunakan untuk mengetahui nilainilai koefisiennya agar tidak bias. Pengujian asumsi ini harus dilakukan sebelum menganalisis dengan regresi berganda. Berikut ini hasil pengujian asumsi klasik :

\section{a. Uji Normalitas}

Penelitian ini menggunakan uji normalitas yang dilakukan dengan menggunakan uji kolmogoro-smirnov untuk menguji apakah dalam model regresi, variabel pengganggu atau residual memiliki distribusi normal. Nilai residual dapat dikatakan normal jika probabilitas signifikan > 0,05. Model regresi yang baik adalah jika nilai residualnya berdistribusi normal.

\section{Tabel 1.2}

Hasil Uji Kolmogorov-Smirnov Test

\begin{tabular}{|l|r|}
\hline Kolmogorov-Smirnov Z & 1,033 \\
Asymp. Sig. (2-tailed) &, 236 \\
\hline
\end{tabular}

Sumber: Hasil Output SPSS Versi 20 (data diolah), 2018

Dari tabel 1.2 dapat dilihat bahwa tingkat signifikansi one samplekolmogoro-smirnov menunjukkan angka 0,236, sehingga dapat disimpulkan bahwa data berdistribusi normal karena nilai signifikan 0,236 lebih besar dari 0,05 . Model regresi dapat digunakan 
untuk menguji hipotesis karena data berdistribusi normal.

\section{b. Uji Multikolonieritas}

Uji multikolinieritas digunakan untuk mengetahui ada tidaknya variabel independen memiliki kemiripan dengan variabel independen lain dalam satu model. Deteksi multikolinieritas pada suatu model dapat dilihat dari beberapa hal, yaitu jika Variance Inflation Factor (VIF) tidak lebih darih 10 dan jika nilai Tolerance tidak kurang dari 0,1 maka model dapat dikatakan terbebas dari multikolinieritas. (Agung, 2005:58). Diperoleh pembiayaan mudharabah (X1) dan musyarakah (X2) memiliki nilai
Tolerance dan VIF yang sama yaitu nilai Tolerance sebesar 0,416 dan nilai VIF sebesar 2,401. Hasil tersebut menandakan bahwa tidak ada multikolinieritas.

\section{c. Uji Heterokedastisitas \\ Uji heterokedastisitas}

digunakan untuk menguji apakah dalam sebuah model regresi terjadi ketidaksamaan varian. Model regresi yang baik adalah model yang tidak terjadi heterokedastisitas. Untuk mendeteksi adanya heterokedastisitas dapat dilakukan dengan menggunakan scatter plot. Apabila tidak terdapat pola yang teratur, maka model regresi tersebut bebas dari masalah heterokedastisitas.

\section{Gambar 1.2}

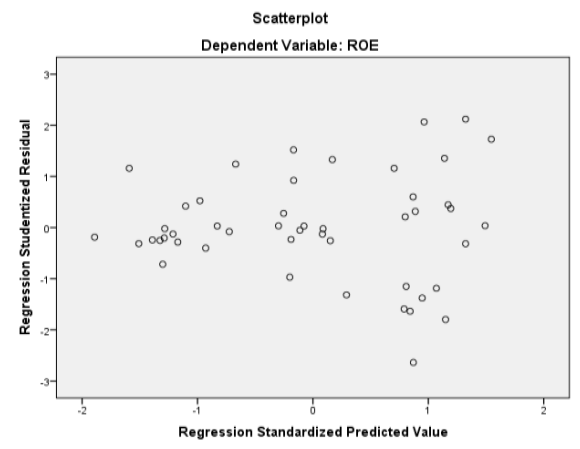

Sumber: Hasil Output SPSS Versi 20 (data diolah), 2018

Dari Gambar 1.2 diatas terlihat bahwa titik yang terdapat pada grafik scatterplot menyebar secara acak serta tersebar baik di atas maupun dibawah angka 0 pada sumbu Y. Hal ini dapat disimpulkan bahwa tidak terjadi heterokedastisitas pada model regresi, sehingga model regresi layak dipakai untuk memprediksi variabel dependen berdasarkan masukan variabel independen.

\section{d. Uji Autokorelasi}

Uji autokorelasi merupakan pengujian asumsi dalam regresi dimana variabel dependen tidak 
berkorelasi dengan dirinya sendiri. Dalam penelitian ini ada tidaknya terjadi autokorelasi dilakukan dengan uji Durbin-Watson. Diperoleh nilai Durbin-Watson adalah sekitar 0,693. Nilai Durbin-Watson yang di dapat berada di antara -2 sampai +2 atau -2 $<\mathrm{DW}<+2$ yang menunjukkan bahwa tidak terdapat autokorelasi dari setiap variabel penelitian pada model regresi ini.

\section{Pengujian Hipotesis}

Uji ini bertujuan untuk mengukur seberapa besar kemampuan model dalam menerangkan variabel-variabel terkait.

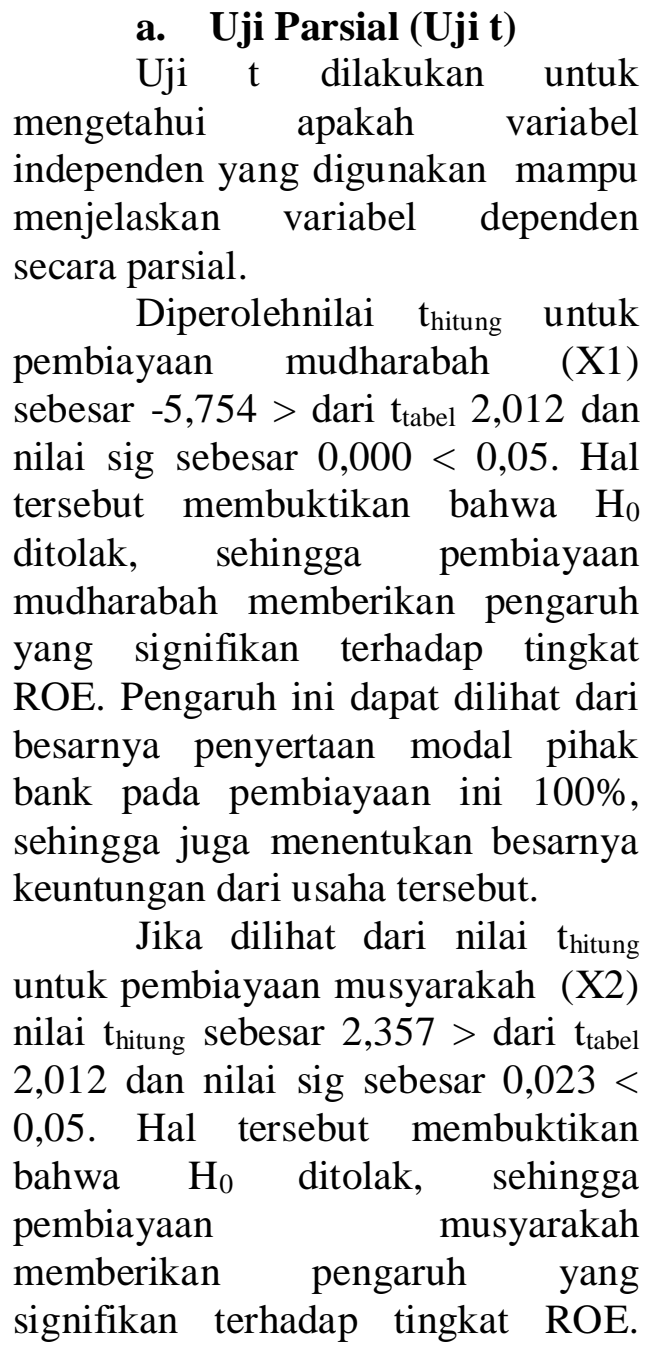

Berdasarkan hasil tersebut, pengaruh yang ditimbulkan pada pembiayaan musyarakah ini juga sama halnya dengan pembiayaan mudharabah. Perbedaannya hanya pada pembiayaan musyarakah, resiko yang ditanggung pihak bank lebih kecil, karena penyertaan modal dan penanggungan kerugian akan dibagi oleh masing-masing pihak.

\section{b. Uji Simultan (Uji F)}

Uji $\mathrm{F}$ dilakukan adalah untuk mengetahui apakah variabel independen yang digunakan mampu menjelaskan variabel dependen secara bersama-sama.Diperoleh pembiayaan mudharabah dan pembiayaan musyarakah berpengaruh signifikan (nyata) terhadap ROE. Hal ini dapat dilihat dari nilai signifikan $0,000<0,05$, sedangkan $F_{\text {hitung }}$ sebesar 21,550> dari $\mathrm{F}_{\text {tabel }} 3,20$, sehingga menerima $\left(\mathrm{Ha}_{2}\right)$ dan menolak $\left(\mathrm{HO}_{2}\right)$.

\section{Koefisien Determinasi $\left(\mathbf{R}^{2}\right)$}

Koefisien determinasi merupakan persentase variasi dependen yang dapat dijelaskan oleh variasi variabel independen.Diperoleh nilai $\mathrm{R}^{2}$ ( $\mathrm{R}$ Square) sebesar 0,489. Hal ini menunjukkan persentase pengaruh variabel independen terhadap variabel dependen sebesar 48,9\%. Variasi variabel independen yang digunakan mampu menjelaskan sebesar 48,9 \% variasi variabel dependen. Sedangkan sisanya sebesar $51,1 \%$ dipengaruhi atau dijelaskan oleh variabel lain yang tidak dimasukkan dalam variabel ini.

Angka koefisien korelasi $\mathrm{R}$ dari tabel diatas sebesar 0,699 menunjukkan bahwa hubungan antara variabel independen dengan 
variabel dependen adalah kuat, karena memiliki koefisien korelasi $\mathrm{R}$ diatas 0,5 .

\section{Analisis Regresi Berganda}

Berdasarkan hasil pengolahan data pembiayaan mudharabah dan musyarakah terhadap ROE diperoleh hasil regresi dapat dilihat pada tabel sebagai berikut:

Tabel 1.3

Koefisien Regresi

\begin{tabular}{|c|c|c|c|}
\hline \multirow{2}{*}{\multicolumn{2}{|c|}{ Model }} & \multicolumn{2}{|c|}{$\begin{array}{c}\text { Unstandardized } \\
\text { Coefficients }\end{array}$} \\
\hline & & B & Std. Error \\
\hline \multirow{3}{*}{1} & (Constant) & 102,698 & 16,080 \\
\hline & Ln_X1 & $-11,689$ & 2,031 \\
\hline & Ln_X2 & 3,954 & 1,678 \\
\hline
\end{tabular}

a. Dependent Variable: ROE

Sumber: Hasil Output SPSS Versi 20 (data diolah), 2018

Berdasarkan Tabel 1.8 menunjukkan persamaan regresi yang menjelaskan ada atau tidaknya pengaruh antara variabel independen dengan variabel dependen. Melalui hasil pengolahan data maka diuraikan pada tabel 1.3 diperoleh persamaan sebagai berikut:

\section{$Y=102,698-11,689 X_{1}+3,954 X_{2}$}

Persamaan $r \begin{array}{r}\text { regresi } \\ \text { adanya }\end{array}$
menunjukkan bahwa antara pembiayaan
pengaruh dan musyarakah
mudharabah dan
terhadap tingkat ROE. Hal ini dapat
dilihat dari koefisien b1 sebesar -
11,689 , Hal ini menunjukkan bahwa
jika pembiayaan mudharabah

\section{PENUTUP}

\section{Kesimpulan}

Berdasarkan analisis data dan pembahasan hasil penelitian, dapat diambil kesimpulan sebagai berikut:
1. Variabel
pembiayaan mudharabah

mengalami kenaikan 1 poin maka akan mengakibatkan menurunnya Return On Equity (ROE) yang didapat sebesar 11,689. Nilai tersebut membuktikan bahwa pembiayaan mudharabah memiliki pengaruh negatif terhadap tingkat ROE.

Jika dilihat dari koefisien b2 sebesar 3,954, Hal ini menunjukkan bahwa jika pembiayaan musyarakah mengalami kenaikan 1 poin maka akan mengakibatkan meningkatnya Return On Equity (ROE) yang didapat sebesar 3,954. Nilai tersebut membuktikan bahwa pembiayaan musyarakah memiliki pengaruh positif terhadap tingkat ROE.

berpengaruh negatif terhadap ROE pada Bank Pembiayaan Rakyat Syariah di Indonesia.

2. Variabel pembiayaan musyarakah secara parsial berpengaruh positif terhadap ROE pada Bank Pembiayaan Rakyat Syariah di Indonesia. 
3. Variabel pembiayaan mudharabah dan musyarakah secara bersama-sama (simultan) berpengaruh positif terhadap ROE pada Bank Pembiayaan Rakyat Syariah di Indonesia.

\section{DAFTAR PUSTAKA}

Abdullah, Ma'ruf. (2014).

Manajemen Bisnis Syariah.

Yogyakarta: Aswaja Presindo. Antonio, Muhammad Syafii. (2011).

Bank Syariah : Dari Teori ke

Praktek. Jakarta: Gema Insani Press.

Asiyah, Binti Nur. (2015). Manajemen Pembiayaan Bank Syariah.Yogyakarta: Kalimedia.

Ghozali, Imam. (2011). Aplikasi Analisis Multivariate Dengan Program SPSS. Semarang: Badan Penerbit Universitas Diponegoro.
Karim, Adiwarman. (2014). Bank Islam Analisis Fiqh dan Keuangan. Jakarta: PT. Raja Grafindo Persada.

Kasmir. (2014). Bank dan Lembaga Keuangan Lainnya. Jakarta: PT Raja Grafindo Persada.

Naf'an. (2014). Pembiayaan Musyarakah dan Mudharabah. Yogyakarta: Graha Ilmu.

Tandelilin, Eduardus. (2010). Portofolio dan Investasi Teori dan Aplikasi. Yogyakarta: Kanisius.

Usman, Abdul Halim. (2015). Manajemen Strategi Syariah (Teori, Konsep dan Aplikasi). Jakarta: Zikrul Hakim.

Veithzal, Rivai (2010). Islamic Banking Sebuah Teori, Konsep, dan Aplikasi. Jakarta: PT Bumi Aksara. 